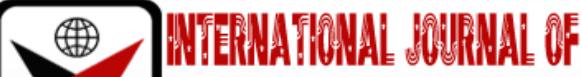

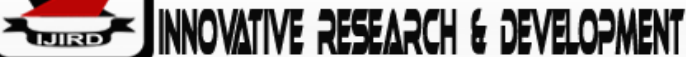

ISSN $2278-0211$ (Online)

\section{Impact of Multinational Oil Companies in Oil Producing Communities in Niger Delta, Nigeria}

Friday O. Iyanam
Assistant Researcher, Department of Defense and Security Studies,
Institute for Peace and Conflict Resolution Abuja, Nigeria
Omini Ubi Ubi
Assistant Lecturer, Department of Public Administration
University of Calabar, Calabar, Nigeria
Ruth Ero
Assistant Researcher, Department of Democracy and Development Studies
Institute for Peace and Resolution Abuja, Nigeria

\begin{abstract}
:
The paper analyzes the impact of Multinational Oil Companies in oil producing communities in Niger Delta, Nigeria. It is very important to note that the activities of the multinational oil companies in the oil rich Niger Delta have both positive and negative impacts. The negative impact is responsible for the state of insecurity in the region and Nigeria in general. When the oil exploration threatens inhabitants of oil communities, the people react through attacks of oil facilities which are likely to crash the oil sector which is the mainstay of the Nigerian economy. The results are job loss, kidnapping, crime and other nefarious activities which are capable of strengthening insecurity. The structural functionalism theory was used to analyze the impact of multinational companies in oil producing communities in Niger Delta This paper proffers solution that can address the negative impact and security implications of the multinationals.
\end{abstract}

Keywords: Multinational oil companies, Niger delta, oil producing communities, insecurity, Nigeria

\section{Introduction}

In Nigeria the Federal government and the oil corporations are partners in the exploration and exploitation of the oil resource, but there has been no significant policy change toward the welfare of the oil producing communities. The value system of the government and that of multinationals differ in their objectives, but the strength of their common economic interest overrides all local rights to the mineral resource. The host government owns all subsurface mineral wealth by law. The state perceives the presence of multinationals with technology and capital as a vehicle for fostering economic growth and relevant core process upon which all other aspects of social and economic development depend. Hence, the multinationals strive primarily to increase their shareholders' wealth and to maintain the interest of their parent company, usually headquartered in a foreign metropolis. The activities, then, of multinational corporations are primarily designed to benefit the absentee parent body and are divorced from the host community welfare. Bock et al. (1984) wrote that they have created calculus of corporate welfare separate from community welfare.

In recent times, there has been serious considerable interest in the process of globalization fueled by Multinational Corporations. These entities spread into every nooks and crannies of the globe and reshape countries in which they set operation regardless of geographical distances and boundaries (Kolk and Van Tulder, 2010). Nigeria is not an exception in the operation of these multinational companies, be it in the agriculture, oil, health and power sectors among others. Nigeria is always a target for multinationals considering her vast population, mineral resources and geographical location, thus the increased interest of multinational companies. In as much as multinationals have their advantages and disadvantages and purposely driven by profit making at the expense of the country of operation and always ploughing back profit to its home country.

For Zaharia and Grundney (2011) the debate encompassing the process of globalization have illuminated many concerns that MNCs may be searching for profits to the detriment of the local communities, environmental quality, labor force and employees. This is the essence for this paper which is beaming its search light on the impact of multinational oil companies in Oil producing communities in Niger Delta, Nigeria. The oil industry in the Niger Delta is dominated by Multinationals Corporations such as Chevron, Texaco, Exxon-Mobil, Total, Agip, Shell, ELF and the Nigerian National Petroleum Corporation (NNPC). There are over 600 oil fields, 5,248 onshore and offshore oil wells, 10 export terminals, 
275 flow stations, 2 major refineries and a Liquefied National Gas Project. As at 2007, statistics produced in the Niger Delta which amount to a staggering National Revenue of 29.8 trillion naira (Tell, February, 18, 2008).

Though MNCs engaged the Federal Government before they are allowed to conduct businesses in Nigeria. These companies relate directly with the government in terms of the regular payments of taxes and royalties. They also relate with the various states governments where their operations are conducted, their relationship with the immediate communities where crude oil is drilled have informal relationship with the MNCs. This is the reasons why Niger Delta Youths sensed the total neglect of the area by the government and began to attack oil installations, economic sabotage, kidnapping of expatriates' workers and making the state ungovernable with negative consequences on the revenue generation of the country.

Attacks on oil facilities by the Niger Delta Avengers (Militant group) and other militias contributed to Nigerian economy sliding into recession that bastardize the economy in 2015 and the effects were colossal, including non-payment of salaries to workers for many months by some states due to dwindling Federal allocations. In this paper, the impacts of multinational oil companies to oil producing communities in Niger Delta would be elucidated at both positive and negative impacts, consequences and security implications and the way forward which included proffering solutions to insecurity in Nigeria which is escalating on daily basis.

\subsection{Conceptual Clarification}

For a proper understand of this paper, it is necessary to conceptualize the following terms: Multinational oil companies, Niger Delta, Oil Producing community, Insecurity

\subsection{Multinational Oil Companies}

Multinational companies are organizations that owns or control production of goods and services in at least one country than its home country (Pitelis; Christos; Roger and Sedge 2000). Multinational corporations help to maintain the spirit of globalization whose key role is to reduce the entire world into a global village. Multinational companies mostly are foreign organizations that embark on foreign direct investment in many countries and also a pedestal for job creation and foreign exchange. It also helps in exchange of expatriates' business ideas in the host country. Multinational corporations are driving the emergence of new markets, industries, technologies and business models as well as unprecedented crossborder financial flows and expanded global value chains (David and Jane, 2017). Some are of the interest of aiding innovative market driven approaches and public private partnership with the potential to address challenges that have traditionally been the purview of public sector, more notably in the aspect of poverty reduction,

Economic exclusion, environmental sustainability, humanitarian relief, health and human right (David and Jane, 2012).

In recent times there has been serious considerable interest in the process of globalization which is inflamed worldwide by Multinational Corporations. These entities spread into every corner of the globe and reshape countries in which they set operations regardless of geographical distances and boundaries (Kolk and Van Tulder, 2010). Nigeria is not an exception in the operation of these multinational companies, be it in the agriculture, oil, health and power sector among others. Nigeria is always a target for multinationals considering her large population, mineral resources and geographical location, thus the increased interest of multinational companies. In as much as multinationals have their advantages and disadvantages and purposely driven by profit making at the expense of the country of operation and always ploughing back profit to its home country. Eg. Texaco, Exxon-Mobil, Total, Agip, Shell, ELF.

\subsection{Niger Delta}

In the Niger Delta, more than $90 \%$ of Nigeria national oil fields, which are among the ten largest oil- producing countries in the world, are concentrated. In the year 2000 the Christian (98\% Ijaw-Christians) and anti-Islamic rebel group movement for the liberation of the Niger Delta was created, mostly from Ijaw people. They demanded the nationalization of the oil resources of Nigeria and reinforce their demands with the abduction of oil workers, pipeline explosions and opposition from the Nigeria army. The conflict arose when significant oil fields were discovered on the shelf of Nigeria development by multinational corporations (Royal dutch shell, chevron) infringed upon the interest of the local people. Various ethnic groups, the strongest of which are the Movement for the Survival of the Ogoni people, engage in attacks on drilling platforms and attacking police stations. The armed conflict in the Niger Delta arose in the early 90s and, unfortunately, continues to this day. The potential oil production in the Niger Delta is three million barrels per day. However, in practice, in recent years, less than two million (1.9 million barrels per day. The activities of movements contributed to the destruction of the economy.

\subsection{Oil Producing Communities in Niger Delta, Nigeria}

Oil was discovered in Oloibiri community, the present day Bayelsa State in commercial quantity in 1956, but today the town is almost a ghost town considering the negative impact of oil exploration in the area and neglect (Ubi, 2015). Oil producing communities can be found in states like Bayelsa, Akwalbom, Delta, Rivers, Cross River, and Ondo. These states fall under the purview of Niger Delta, although Ondo State can be seen among the South Western State, but with oil discovery in commercial quantity it is under the platform of oil producing states. These communities have faced positive and negative impacts of these multinational companies in the past and present. According, to Micheal, Ubi and Eucharia (2012). Oil industry has created situation for social dislocation and communal violence in the oil rich Niger Delta Region. They further expressed that while the direct effect of oil and gas production are borne by the Niger Delta States, other communities also suffer from direct impact of oil and gas industrial activities. For Osouka (2007), exploration of oil and 
gas presents multiple forms of environmental degradation. Oil pollution kills fish, other food sources and fish larvae and damages the ability of fish to produce, causing both immediate damage and long-term harm to fish stocks.

These communities have suffered untold hardship from the activities of the oil companies and the government who directly benefits from the companies. Although, the government has tried in past time to see how development can enhance in these communities and states by establishing laws backing financial benefits to the communities. For instance, on monthly basis the Federal Government of Nigeria pays thirteen percent derivation to oil producing states to ensure that development is brought to bear in these communities. Again, the establishment of the Niger Delta Development Commission (NDDC) whose mandate is to further deepen development in the rural oil producing communities and the states that falls within Niger Delta. While on the part of these companies they have tried to provide infrastructure to better the lives of the people. But it seems as if the negative impact outweighs the positive, thus the reason why crises persist with high level of insecurity which is a bane to political and economic development of Niger Delta and Nigeria in general. This paper is a policy paper that would direct the path of peace in the region and Nigeria. These communities are blessed by nature to have this mineral deposit in their domain and should be treated with the highest level of regards. The proliferation of militant groups in the region was the neglect by the government and activities of the multinational oil companies, but issues responsible for hostilities can be resolved and proffer peace.

\subsection{Positive Impact of Multinational Oil Companies in Niger Delta}

Agriculture used to be the mainstay of the economy and had provided jobs for the teeming population, but the advent of oil production in commercial quantity dislodged the agricultural sector, the government developed more interest in the oil sector and invested much in the establishment of refineries and other oil facilities, thus the creation of jobs. Loco (2015) posited that the oil sector has provided jobs for fifty thousand Nigerians and non-Nigerians for the past forty years. These jobs are direct and indirect in the oil sector. The oil sector is the main source of revenue generation in Nigeria and serves as a means of foreign exchange to the Nigerian economy. The development of Abuja and other big cities, the development of infrastructure in Nigeria came from money realized from oil. The establishment of more public universities in Nigeria and their running cost is from oil revenue. On the positive impact of Multinational Oil companies in Niger Delta, these companies have embarked on series of corporate social responsibilities in the areas of building schools, job provision, scholarship, jobs and infrastructural development.

\subsection{Negative Impact of Multinational Oil Companies in Niger Delta}

The negative impact of the multinational oil companies outweighs the positive due to the role the companies play in the development of the oil sector and the economy of Nigeria. The negative impacts of these companies are limited to oil producing communities, but the corresponding effect in the country is on the basis of the reaction of the people through militancy which is the destruction of oil facilities, thus, affecting oil supply and a sabotage to the economy. Looking at the negative impacts of the activities of multinational oil companies in Niger Delta, SPDC (2002) recorded that in 2001 the Western Operation of Shell Petroleum experienced a total of 115 incidents of oil spills in the Niger Delta. In 2002, Waste disposal and pollution by the Warri refinery and petrochemicals company (WRPC)loaded spoiled fish and reportedly caused a number of deaths among the Itsekiri people (Michael, Ubi and Eucharia, 2012). According to Osowka (2007) exploration of oil and gas present multiple forms of environmental degradation. Oil pollution kills fish, their food sources and fish stocks. Oil pollution damages the ability of fish to reproduce, causing both immediate and long-term to fish stock.

Oil exploration in oil producing communities also have affected agricultural land and messed up the eco-system. The protracted problem between Ogoni people and the oil multinational companies on oil production that have contributed to the devastation of farmland and crops thus making it difficult for the people to plant crops. There are other negative impacts that are responsible for insecurity in the region.

\subsection{Consequences and the Security Effect of the Negative Impact of the Multinational Oil Companies in Nigeria}

The consequences and the security issues of the multinationals is the reaction of the people of Niger Delta through the proliferation of militant groups. For instance, the Niger Delta Avengers (NDA) contributed into frustrating Nigeria's economic recession by blowing up facilities thereby reducing the supply of the oil. There are other groups that specialized in the kidnapping of expatriate oil workers and attacks on oil installation which they used to draw the attention of the government. There are series of times that the Niger Delta people have threatened to declare Niger Delta Republic as a result of problems affecting the region. They have killed oil workers in the event of preventing them to stop oil production. The reaction of these militant groups has escalated the state of insecurity in Nigeria which is now a social problem considering the increased and heightened banditry and Boko Haram nefarious activities in the north. Whenever, there is crisis in the oil rich Niger Delta the country suffers a lot. It hampers oil investment, affects foreign direct investment and business transaction. Job is often lost, lives and property destroyed. When people lost their jobs, they take to crime and other nefarious actions that are inimical to the development of the society.

\section{Framework: Structural Functionalism}

The structural functionalism theory is used to explain, describe and predict the article. The theory explains how the society or environment functions the way it does by emphasizing the relationship among the various small institutions that make encompasses the society and drive government policy towards societal development. The primary concept of this theory is collective conscience, value consensus, social order, Education, family, crime and deviance and the media. Sociologists like Talcott and Durkheim have been concerned with the search for the functionality of the society, since a society that is characterized with violence and negativity can be in total disarray. This article is on the Impact of 
Multinational Oil Companies in Niger Delta. The negative and positive impacts have been visible and clearly stated. The functions of the Nigerian National petroleum Company which is the umbrella institution that oversee the affairs of the oil sector in Nigeria and also has the mandate to promote the positive impacts and mitigate the negative issues of the various oil companies in the oil producing communities and the corresponding response on how militant groups .The Nigerian government which is an institution is related to structural functionalism must address the problems that are capable of derailing the interests of the oil rich region and Nigeria in general .The government through the petroleum ministry should ensure that money for development of the oil producing areas are adequately utilize in terms of development .Persons from oil producing communities should be consider for job placements, infrastructural development ,scholarship. Combat environmental disarray. This will help to boost the relationship among the host communities, multinationals and the government which would further bring the required economic growth and development.

\section{Conclusion}

Crude Oil, which is the black gold of the twentieth century and one of the most lucrative sources of wealth, is now the most important energy source in Nigeria. Although its usage has created some of the largest fortunes and has helped to achieve impressive economic growth and development, little or no attention has been directed to the impact of this exploitation on the oil producing communities. This lack of attention can be attributed to the pragmatic and international orientation of oil emprises, which are almost exclusively managed and operated by Multinational Corporation from a capitalistic point of view, without regard to the welfare of the producing communities. Dokwame Nkrumah words of twenty-five years ago still apply today? If so, only the government of the producing state can exercise its sovereign power to reverse the imperialist trend and protect the welfare of its people (Augustine A.Ikein 1990). State government must make the multinationals socially accountable for their activities in the host communities if truly balance of development is to be achieved. These corporations may well intend to see genuine development for the people, but good intentions are not enough without practical evidence. It requires sound effort to implement their corporate social responsibility to the host communities, an implementation that would ensure the development of indigenous people such that all parties on the line of economic progress (multinational, government and people) can benefit equitably.

\section{Recommendations and the Way Forward}

The way forward to end the negative impact of the activities of multinational oil companies in Niger Delta and stimulate peaceful atmosphere for oil production to thrive and the local and natural economies to have a boost and curtail insecurity. The following recommendations are made.

- The multinational oil companies operating in the oil rich Niger Delta should embark on

- Corporate Social responsibilities in the aspect of jobs, infrastructural development, economic empowerment, human capital development etc.

- Cordial relationship and formidable communication between host communities and the oil companies. This can be achieved through the conduct of monthly meeting and feedback mechanism. This approach is an all-inclusive policy that will give the people hope and sense of belonging.

- The government of the federal republic of Nigeria and these multinationals should be proactive in preventing oil spill, but in the event of oil spill and other environmental degradation as a result of oil production activities there should be prompt response to weaken the damage of the spill on the communities and their farmlands.

- The security agents should be at alert in case there are groups who may want to scuttle the exploration of oil for political reasons to stop this nefarious act by the disgruntled elements.

- The Multinational Oil Companies Should order for Environmental Impact Assessment of host communities in line with international best practice and extant Laws. It will assist in tackling unforeseen environmental hazard.

- Appropriate Government Ministry, Department and Agencies should be empowered to closely monitor the Operation Oil Companies in the Oil Producing Communities to Ensure Compliance with Sustainable Development Practice, Corporate Social Responsibility and Environmental Governance.

\section{References}

i. Augustine A. kein (1990). The Impact of Oil on a Developing Countries, the Case of Nigeria

ii. David, C and Jane, N (2012). Global Corporators, Global Impact. Brookings Global Expert.

iii. Loco, S (2015). Boosting the Oil Sector for Viable Economy. Unpublished Article

iv. Michael, Bagehebo, Ubi, Peters and Eucharia, N. Nwagbara (2012). Environment damage caused by the activities of multinational oil grants in the Niger Delta Region of Nigeria. Journal of Humanities and Social Sciences (JHSS). Pg 9-13

v. Osuwka (2007). Multiple forms of environmental degradation by exploration of oil and gas. Retrieved 14 November 2012. http/wwwearthlife.org.za/wondpress/wpcontent/upload/2009/or/sense-29pdf

vi. Pitelis, O. Christo, U and Sogdan (2002). The nature of transuatural firm. Routledge P.H. 72.

vii. Shell petroleum development company, Western Operation, Environment Department Report. August, 2002.

viii. Tell magazine, February 18, 2008.

ix. Ubi, U. O. (2017). Community Based Organizations and the development of rural areas in Yakurr Local Government Area, Cross River State, Nigeria. (Unpublished Msc Thesis, University of Calabar).

X. Zaharia, R. M and Grundrey, D (2011). Corporate Social Responsibility in the context of financial crisis: A comparison between Romania and Lithuanian. Amfeteru Economic, 13(29), 195-206. 